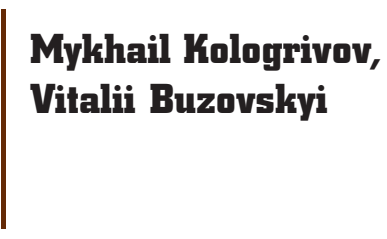

\title{
DEVELOPMENT OF THE SYSTEM OF ENERGY AND RESOURCE SAVING DURING THE OPERATION OF THE GAS PUMPING UNIT
}

The object of research is the fuel gas system of a gas turbine engine. The study of the use of secondary energy resources of the gas-pumping unit at the compressor station of the main pipeline has been carried out. The work of a gas turbine engine, including the work of the fuel gas system, is considered. The main drawback of the fuel gas system is revealed - ineffective use of excess gas pressure. An informational analysis of the options that eliminate the identified drawback is carried out. It is shown that in order to eliminate the disadvantage, it is advisable to use a turbo-expander at the compressor station to utilize the excess pressure of the fuel gas. It is also shown that the operation of a fuel gas turboexpander to drive an additional air compressor as part of a gas turbine engine is impractical. An expander-generator set with the generation of additional electricity at the compressor station is recommended for use.

Modeling the operation of the utilization system made it possible to recommend constructive proposals for its improvement. A schematic diagram of a system for the complex utilization of excess pressure of fuel gas and heat of combustion products from the operation of a gas turbine engine is proposed. The system of complex utilization includes parts-generator unit, heat exchanger for cooling process gas and heat exchanger for firing gas. Regenerative heating of fuel gas up to $250^{\circ} \mathrm{C}$ reduces energy consumption for heating it up to the ignition temperature.

A model of a robot installation of the type GPU 16/56-1.44 (Ukraine) is carried out. It is determined that when a component engine of the J-59 (Ukraine) type with a shaft power of $16 \mathrm{MW}$ operates, it is possible to additionally receive $102 \mathrm{~kW}$ of electricity and save $64 \mathrm{~m}^{3} / \mathrm{h}$ of fuel gas. It is revealed that the subcooling of the process gas does not play a significant role in reducing energy consumption during its transportation. It is recommended to use the process gas to heat the cold fuel gas stream downstream of the turboexpander to positive temperatures. The integrated utilization system is not a simple connection of an expander-generator set and two heat exchangers along the flow of the fuel gas. As a result of its operation, a significant reduction in the consumption of fuel gas and electricity is achieved. The disadvantages that hinder the implementation of a comprehensive disposal system are identified. This is the use of equipment for generating electricity at a compressor station. It is uncharacteristic for the operation of the station and requires additional qualifications in service. It is also required that the characteristics of industrial expander-generator sets correspond to the fuel gas consumption of a gas turbine engine.

Keywords: fuel gas, gas turbine engine, disposal system, overpressure, thermal emissions, expander.

\section{Introduction}

The depletion of resources of large gas fields in the process of their development and the relatively expensive development of new small gas fields have led to the problem of energy and resource conservation in the industry. It should be concluded that when transporting natural gas through trunk pipelines, there are significant potential opportunities for energy and resource conservation. Predictive calculations of specialists have shown that only due to the rational use of resources, it is possible to halve the consumption of natural gas for own needs during its pipeline transport [1].
There are several ways that lead to the effect of energy and resource saving: administrative and legal, financial and economic, organizational and technical, research, testing, production and technological. Industry and corporate interests in hydrocarbon transportation and power generation should also be taken into account. The research approach is considered in the work.

\section{The object of research and its technological audit}

The object of research is the fuel gas system of a gas turbine engine. 
Gas saving provides for an integrated approach. First, by reducing direct gas losses during the operation of trunk pipelines. Secondly, by saving fuel gas during the operation of gas turbine drives. Thirdly, to obtain additional positive effects (generating electricity, cold, performing mechanical work, growing fruits and vegetables, heating oil, etc.) through the use of waste heat boilers and a turbo expander.

The problem is of practical importance. For example, more than 700 gas pumping units have been installed at compressor stations in Ukraine. Including $59 \%$ of units with gas turbine engines, $22 \%$ of units with electric drive and $19 \%$ of gas engine compressors [2].

A promising direction of energy and resource saving at the compressor station is the use of the potential energy of the fuel gas and the thermal resources of the combustion products, which are discharged during the operation of the gas turbine engine. It seems possible to increase the efficiency of the gas-pumping unit by reducing the consumption of fuel gas of the engine and additional generation of electrical energy.

The gas turbine engine consumes gas from the main pipeline during its operation. Fig. 1 shows a schematic diagram of gas extraction for the auxiliary needs of the engine [3]. Bleed gas is divided into starting, fuel and pulse. The diagram shows the technology for supplying starting gas to an axial air compressor and fuel gas to a combustion chamber.

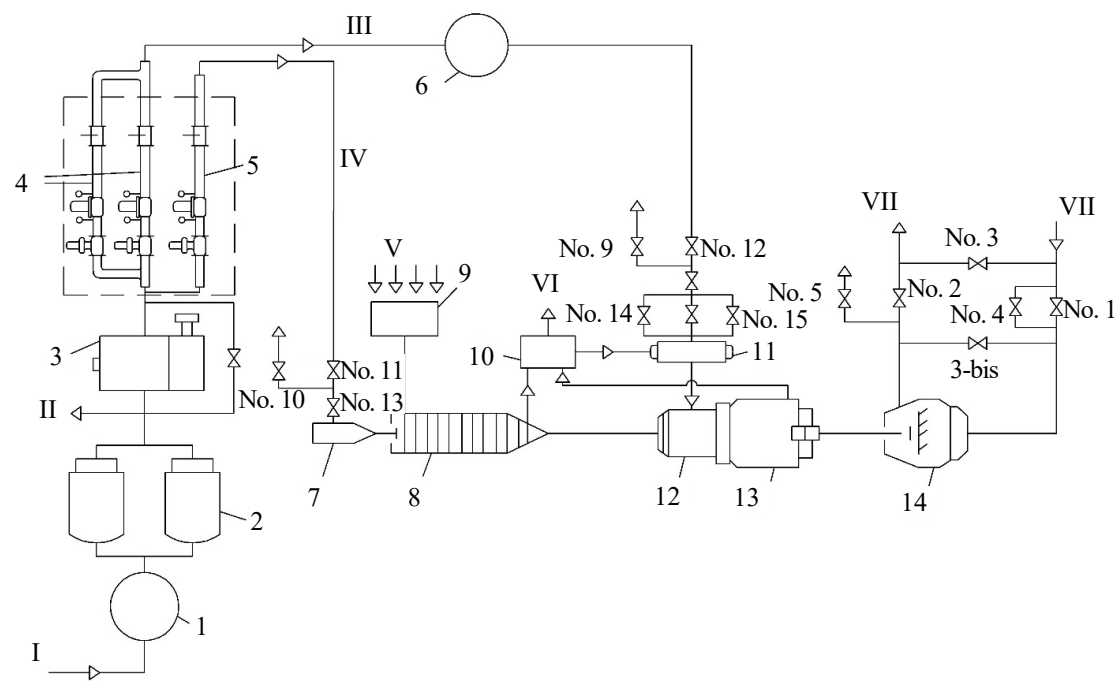

Fig. 1. Schematic diagram of starting and fuel gas of a gas compressor unit: 1 - cyclone separator; 2 - separator filters; 3 - gas heater; 4 - fuel and starting gas reduction unit; 5 - pulse gas reduction unit; 6 - separator; 7 - start gas turbo expander; 8 - axial air compressor;

9 - air intake chamber; 10 - heat exchanger; 11 - the combustion chamber; 12 - high pressure turbine; 13 - power turbine; 14 - supercharger; I - gas for own needs; II - impulse gas; III - fuel gas; IV - starting gas; V - air; VI - combustion products; VII - process gas

- pipelines;
The fuel and starting gas system has a modular design and includes the following equipment (Fig. 1):

- cyclone separator (1), or cleaning unit;

- filter separator (2), or drying unit;

- heaters (3);

- block for reduction of starting (5) and fuel (6) gas;

- measuring device;

- taps No. 9, 12, 14 and 15, as well as stop and control valves of the fuel system;

- launcher or turbo expander (7).

The system operates as follows: the gas taken from the station's technological communications enters the purification unit or gas separator 1, where it is purified from mechanical impurities. Further, the gas enters the filter-separator 2, where it is deeper cleaned from mechanical impurities and moisture. Then the gas enters the heater 3 , where it is heated to a temperature $45-50{ }^{\circ} \mathrm{C}$. The fired heater is a heat exchanger in which a high pressure gas tube bundle is immersed in a diethylene glycol solution. Diethylene glycol is heated using the combustion chamber of this device. Gas heating is carried out in order to ensure the stable operation of the reduction units and prevent its freezing, which can disrupt the operation of the control system.

Before the reduction unit, the gas is divided into two streams: one is directed to the fuel gas reduction unit 4, the other to the starting gas reduction unit 5 . The fuel gas is reduced to a pressure of $0.6-2.5 \mathrm{MPa}$, depending on the air pressure behind the axial compressor (8) of the engine. After the reduction unit, the fuel gas enters the separator 6 , where it is recleaned from moisture that was released during the reduction. The gas then goes to the fuel manifold. Fuel gas enters the combustion chamber (11) through valve No. 12, stop and control valves. Valves 14 and 15 are used for the pilot and pilot burners during the start-up period of the unit. The startup gas in the reduction unit reduces the pressure according to the pressure gauge to $1.0-1.5 \mathrm{MPa}$ and flows through taps No. 11 and 13 to the inlet to the turboexpander (7). The gas expands when the turboexpander impeller rotates to atmospheric pressure. It does a useful job of untwisting the axial compressor and turbine. A turboexpander is a device that serves to reduce the pressure or temperature of a gas to preset values by performing useful work.

The fuel and starting gas system are designed to clean, dry and maintain the required pressure and flow rate before feeding it to the combustion chamber and to the starting device (turboexpander).

It is possible to take gas from various points of technological communications of the compressor station: at the connection point before and after valve No. 20, from the outlet collector of dust collectors and the outlet loop of the compressor shop - in front of the air coolers. The gas pressure at the sampling points is high and amounts to 3-6 MPa.
In the reduction unit, the pressure is reduced to the set values without performing any useful work. The problem under consideration is the use of an additional turbo expander as a functional replacement for pressure regulators in the reduction unit.

\section{The aim and objectives of research}

The aim of research is to solve the problem of utilizing the excess pressure of the fuel gas of a gas turbine engine. This will allow obtaining a significant positive effect due 
to the generation of additional electricity in the expandergenerator units and fuel gas savings.

To achieve the aim, the following objectives are set.

1. To consider the unresolved part of the problem based on the new combined recycling system.

2. To propose the structure of a new combined system for utilization of excess pressure of fuel gas and thermal resources of exhaust gases of a gas turbine engine.

\section{Research of existing solutions to the problem}

Much attention is paid to the search and study of new technologies for energy and resource conservation in the gas transportation industry. State programs on this problem are being adopted. The results of scientific developments by numerous researchers are presented in scientific and technical sources of information [3, 4].

In [5], the task is to assess the reduction of fuel gas consumption due to the use of equipment at the compressor station for utilization of excess fuel gas pressure (Fig. 2).

The diagram in Fig. 2 intentionally simplified in comparison with the circuit in Fig. 1. Many nodes, elements and connections that are in a real gas turbine plant are not shown.

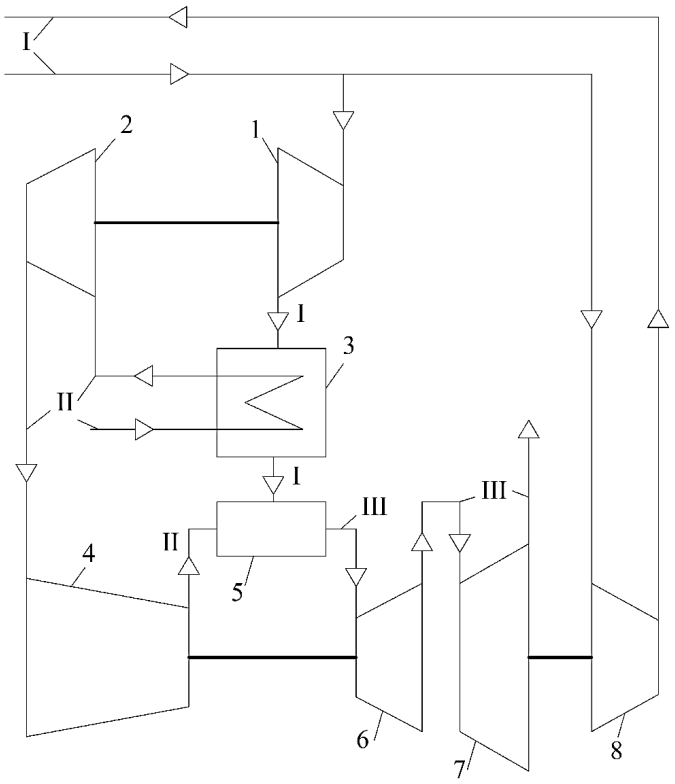

Fig. 2. Schematic diagram of utilization of fuel gas pressure: 1 - turbo expander; 2 - booster air compressor; 3 - heat exchanger; 4 - axial air compressor; 5 - combustion chamber; 6 - high pressure turbine; 7 - power turbine (low pressure turbine); 8 - supercharger (process gas booster compressor); I - natural gas; II - air; III - combustion products

On the other hand, the fuel gas preparation and supply system proposed by the authors is supplemented with an expander (1), a booster air compressor (2), and a recuperative heat exchanger (3).

According to the authors of [5], the principle of utilizing the energy of excess pressure of fuel gas is as follows. The gas pressure is reduced in the turbo expander, which does the useful work of compressing the air in the compressor (2). Atmospheric air enters the compressor (2), pre-cooled in the heat exchanger (3). The air pressure at the outlet of the compressor (2) is less than the pressure in the combustion chamber (5) of the gas turbine engine.
Further increase in air pressure to the required value is carried out in the axial compressor (4). Air supply with a pressure higher than atmospheric pressure on the suction line of the axial compressor (4) reduces energy consumption for its operation.

When expanding the fuel gas in the turboexpander (1) with the simultaneous performance of work, the gas is cooled by tens of degrees Celsius. The cold gas stream cools the ambient air in the heat exchanger (3) in order to reduce the energy consumption in the compressor (2). An increase in the temperature of the fuel gas after the heat exchanger (3) reduces its consumption for combustion.

Let's estimate the quantitative positive effect of the constructive solution proposed by the authors of [5], taking into account the initial data (Table 1).

Table 1

Input data to identify the positive effect

\begin{tabular}{|l|c|}
\hline \multicolumn{1}{|c|}{ Рагаmeter } & Indicators \\
\hline Fuel gas consumption, $\mathrm{kg} / \mathrm{s}$ & 0.519 \\
\hline Fuel gas pressure before the turboexpander, $\mathrm{MPa}$ & 3.24 \\
\hline Fuel gas pressure after turboexpander, $\mathrm{MPa}$ & 1.75 \\
\hline Fuel gas temperature in front of the turboexpander, ${ }^{\circ} \mathrm{C}$ & 20 \\
\hline Ambient air temperature, ${ }^{\circ} \mathrm{C}$ & 25 \\
\hline Air compression ratio & 17.5 \\
\hline Air consumption, $\mathrm{kg} / \mathrm{s}$ & 36.58 \\
\hline
\end{tabular}

Preliminary calculations show:

- the fuel gas flow will be cooled in the turbo expander (1) by $30{ }^{\circ} \mathrm{C}$ from $20{ }^{\circ} \mathrm{C}$ to minus $10{ }^{\circ} \mathrm{C}$;

- the fuel gas flow will be heated in the heat exchanger (3) from minus $10{ }^{\circ} \mathrm{C}$ to $20{ }^{\circ} \mathrm{C}$;

- the air flow will be cooled in the heat exchanger

(3) by $0.5{ }^{\circ} \mathrm{C}-$ from $25{ }^{\circ} \mathrm{C}$ to $24.5{ }^{\circ} \mathrm{C}$;

- utilized power of the turboexpander $28 \mathrm{~kW}$;

- the air pressure after the compressor (2) will be

$1000 \mathrm{~Pa}(0.001 \mathrm{MPa})$ higher than atmospheric;

- reduction of air compression in the axial compressor will be $0.057 \%$.

Thus, from a practical point of view, cooling the air by $0.5{ }^{\circ} \mathrm{C}$ and increasing its pressure on the suction line of an axial compressor (4) by $1000 \mathrm{~Pa}$ is insignificant for the operation of a gas turbine engine.

Possible operational disadvantages of the fuel gas overpressure utilization system include the fact that the number of revolutions of the turbo expander (1), compressor (2), axial compressor (4), high pressure turbine (6) is different. The system should use gears according to the number of revolutions. A change in the fuel gas consumption leads to a more complex coordination of the operation of the nodes.

The fuel gas flow rate must be independent of the air flow rate, since air is used for combustion and for cooling the combustion products to a predetermined temperature. This is not achieved in the known solution, since the air flow rate is tied to the operation of the fuel gas turboexpander.

Another area of using excess fuel gas pressure is the generation of electricity using expander-generator sets [1]. The useful job of a turbo expander is to generate electricity. Calculations and operating experience of expander-generator sets confirm the amount of generated electricity up to 
$50 \mathrm{~kW} /\left(\right.$ thousand $\mathrm{m}^{3}$ per hour), depending on the pressure drop and the efficiency of the gas expansion process in the turboexpander. The working unit includes an expander, a gearbox and a generator. The reducer reduces the speed of the turbine output shaft to the speed of the generator rotor - from 14000 to $3000 \mathrm{rpm}$. This is the production for own needs of relatively cheap and environmentally friendly electricity. The ecological result from the introduction of an expander-generator set is expressed in terms of reduction of greenhouse gas emissions and is measured in conventional tons of $\mathrm{CO}_{2} .1 \mathrm{MWh}$ of clean energy corresponds to an emission reduction of 0.68 conventional ton of $\mathrm{CO}_{2}$.

The third direction in utilization systems is gas heating before its expansion in a turboexpander [6]. The gas entering the expander can be heated in a heat exchanger to a temperature of $300{ }^{\circ} \mathrm{C}$. For heating, part of the gas is burned in the amount of $0.2 \%$ of the flow rate for the turboexpander. In this case, about $75 \%$ of the heat of the flue gases is utilized.

The gas is heated to increase the power of the turboexpander and to provide a positive flow temperature at the outlet from $0{ }^{\circ} \mathrm{C}$ to $10{ }^{\circ} \mathrm{C}$ [7]. The design of the turbo expander is similar to that of a gas turbine. The results of studies of the characteristics of gas turbines [8,9] note a positive effect on the operation of turbines from heating fuel gas.

The third direction in utilization systems is fuel gas heating before its expansion in a turboexpander [6]. The gas before the expander is preheated in a heat exchanger to a temperature of $300{ }^{\circ} \mathrm{C}$. For heating, part of the gas is burned in the amount of $0.2 \%$ of the flow rate for the turboexpander. The heat exchanger recovers about $75 \%$ of the heat of the exhaust combustion products.

The fuel gas is heated to increase the power of the turboexpander and ensure a positive flow temperature at the outlet from $0{ }^{\circ} \mathrm{C}$ to $10{ }^{\circ} \mathrm{C}$. The disadvantage of this method is the increased gas consumption.

The paper [7] investigates the effect of preheating fuel gas before combustion to $350{ }^{\circ} \mathrm{C}$ on the concentration of harmful nitrogen oxides in combustion products. The influence of temperature on fuel gas consumption is not considered.

The design of the turbo expander is similar to that of a gas turbine. The simulation results in [8] show that an increase in the fuel gas temperature increases the power of the gas turbine. The influence of the temperature of the fuel gas on its consumption is not considered.

The paper [9] analyzes the decrease in fuel gas consumption due to its preheating. It is noted that gas savings from preheating in monetary terms are offset by the cost of creating heat exchangers. There remains the question of economical heating of fuel gas due to the heat of the exhaust combustion products.

The work [10] simulates the operation of a gas turbine when burning hydrogen instead of natural gas at different initial temperatures and pressures. An increase in turbine power is noted with an increase in the hydrogen temperature in front of the combustion chamber. The paper does not consider the effect of temperature on fuel consumption, that is, the problem of resource conservation.

The authors of [11] note the expediency of utilizing the potential energy of fuel gas using a turboexpander and utilizing thermal emissions from a gas turbine engine, but do not indicate specific ways to solve the problem.
Thus, the results of the information analysis allow to conclude that the problem of the combined use of the excess pressure of fuel gas with the heat of the waste products of combustion for the purpose of energy and resource conservation has not been solved.

\section{Methods of research}

Simulation of a combined utilization system for supplying fuel gas to the combustion chamber of a gas turbine engine.

Analysis of the technical characteristics of the utilization system elements in relation to the existing industrial gas compressor units.

Performing heat engineering calculations according to standard methods.

\section{Research results}

The fuel gas of the gas turbine engine is taken from the process pipelines of the compressor station. For example, the selection pressure $3.7 \div 5.6 \mathrm{MPa}$ significantly exceeds the fuel gas pressure of $1 \div 2.5 \mathrm{MPa}$ in front of the combustion chamber of a gas turbine engine. In existing compressor stations, the excess potential energy of the fuel gas is lost in the reduction unit on the pressure regulator. On the other hand, when a gas turbine engine is operating, only $30-35 \%$ of the thermal energy of the gases formed during the combustion of the fuel gas is usefully used. Combustion products go into the atmosphere with a temperature of $370 \div 550{ }^{\circ} \mathrm{C}$, depending on the season.

Let's simulate the characteristics of the new combined utilization system using the example of the operation of an installation of the type GPU 16/56-1.44 (Ukraine). The gas compressor unit includes a gas turbine engine of the J-59 type (Ukraine) and a natural gas blower - a compressor of the type $324 \mathrm{HZ} 2-540 / 38-57 \mathrm{M} 1$ (Ukraine) [12, 13].

Characteristics of the J-59 engine: power $-16300 \mathrm{~kW}$; efficiency $-30 \%$; air consumption $-98.5 \mathrm{~kg} / \mathrm{s}$; exhaust gas temperature $-360{ }^{\circ} \mathrm{C}$; compressor - axial with a compression ratio of 12.7: fuel gas consumption $-4940 \mathrm{~m}^{3} / \mathrm{h}$ (at $0{ }^{\circ} \mathrm{C}$ and $0.1013 \mathrm{MPa}$ ). The $\mathrm{J}-59$ engine is designed to drive the blowers of compressor stations. The engine can be operated with a steam heat recovery circuit.

Characteristics of the $324 \mathrm{HZ} 2-540 / 38-57 \mathrm{M} 1$ supercharger: natural gas capacity $-29,900,000 \mathrm{~m}^{3}$ /day $\left(\right.$ at $20{ }^{\circ} \mathrm{C}$ and $0.1013 \mathrm{MPa}$ ); inlet gas pressure $-3.73 \mathrm{MPa}$; outlet gas pressure - $5.59 \mathrm{MPa}$; efficiency - $86 \%$; number of revolutions $-5200 \mathrm{rpm}$. Gas heating during compression at $35^{\circ} \mathrm{C}$.

Fig. 3 shows a diagram of the proposed system for the utilization of excess energy at the compressor station.

Additional elements in relation to typical compressor station systems are an expander-generator set for reducing the pressure of the fuel gas and additional power generation, an additional heat exchanger for cooling the process gas, a waste heat boiler with a heat exchanger for heating the fuel gas.

The diagram (Fig. 3) can be divided into two technological blocks. The first relates to the gas turbine engine and the second to the supercharger.

At existing stations, the first block includes: an air compressor (1), a combustion chamber (2), a high-pressure turbine (3), a power turbine (4), shut-off valves (11), a control valve (12). The second block includes: a blower (6), an air cooler (AC) (7). 


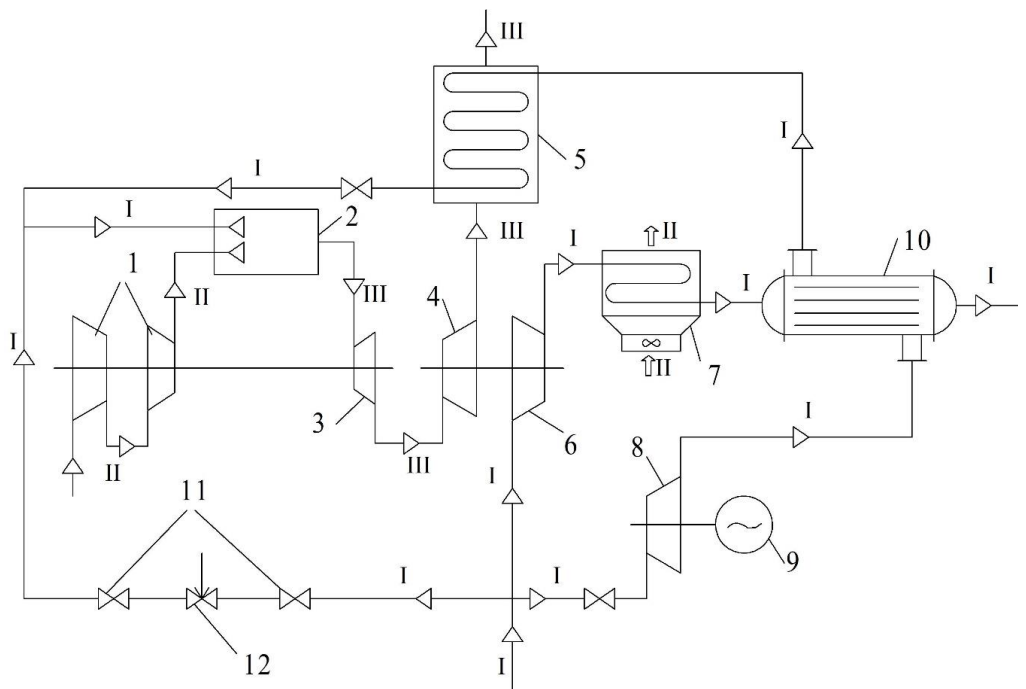

Fig. 3. Waste energy recovery system for fuel gas treatment:

1 - multistage axial air compressor; 2 - combustion chamber; 3 - high pressure turbine; 4 - power turbine; 5 - waste heat boiler; 6 - supercharger; 7 - air cooler; 8 - turbo expander; 9 - electric generator; 10 - heat exchanger; 11 - shut-off and control valves; 12 - pressure regulator; I - natural gas; II - air; III - combustion products

In the proposed new scheme, the first block includes an air compressor (1), a combustion chamber (2), a highpressure turbine (3), a power turbine (4), a turbo expander (8), an electric generator (9), a heat exchanger (10), a boiler heat exchanger (5), shut-off valves (11). The second block includes: blower (6), AC (7), heat exchanger (10). It should be noted that the heat exchanger (10) belongs to both blocks.

Let's consider the purpose of each element of the circuit. Axial multistage air compressor (1) is designed to increase the ambient air pressure to a given pressure of the airfuel mixture in the combustion chamber. The combustion chamber (2) is designed to burn the air-fuel mixture to obtain combustion products of a given temperature and pressure. The high pressure turbine (3) drives the air compressor (1). The power turbine (4) drives the blower (6) The waste heat boiler (5) is designed to heat fuel gas with combustion products. The blower (6) is designed to increase the pressure of the process gas to the specified pressure at the outlet of the compressor station. The air cooler (7) is designed to cool the process gas to a temperature not exceeding $40{ }^{\circ} \mathrm{C}$ at the outlet of the compressor station. The turboexpander (8) is designed to reduce the pressure of the fuel gas to the pressure of the fuel mixture in the combustion chamber (2) by operating as a drive for an electric generator (9). The heat exchanger (10) is designed for additional cooling of the process gas due to the cold fuel gas flow. Shutoff valves (11) are designed to cut off the gas flow. The control valve (12) is designed for a given change in the flow rate and pressure of the fuel gas.

Let's consider the work of the scheme by streams. There are four streams in total: air; fuel gas flow; combustion product flow; process gas flow. A multistage axial compressor (1) sucks in the ambient air and increases its pressure to a given pressure $(1.2 \div 2 \mathrm{MPa})$ in the combustion chamber (2). Fuel gas is taken from the main gas pipeline at the inlet to the compressor station. The initial pressure of the fuel gas is up to $5.6 \mathrm{MPa}$, which significantly exceeds its pressure in the combustion chamber (2). Therefore, it is necessary to use devices to reduce the pressure of the fuel gas. In the existing scheme, the fuel gas pressure is reduced using a control valve (12). In this case, the gas temperature decreases by several degrees due to the Joule-Thomson effect. After reducing the pressure, the gas enters the combustion chamber (2).

In the proposed scheme, the fuel gas from the main gas pipeline enters the turbo expander (8). In a turboexpander, the potential energy of the fuel gas overpressure is used to carry out mechanical work - the rotation of the rotor of an electric generator. When the flow of fuel gas in the turboexpander expands, its pressure decreases to a predetermined one. At the same time, the gas temperature decreases by tens of degrees (up to minus $40 \div 70{ }^{\circ} \mathrm{C}$ ). The cold fuel gas flow enters the heat exchanger (10), in which it is heated to positive temperatures due to the warm process gas flow. Further, the fuel gas is heated in a waste heat boiler (5) to temperatures of $200 \div 300{ }^{\circ} \mathrm{C}$, and then enters the combustion chamber (2).

The flow of combustion products is formed in the chamber (2) during the combustion of the fuel mixture. At the outlet of the chamber, the combustion products are at a given pressure and at a temperature of $1000{ }^{\circ} \mathrm{C}$. Combustion products from the chamber (2) enter the highpressure turbine (3). The stream expands in the turbine, partially reducing its pressure and temperature. The flow energy is converted into mechanical energy - the work of the axial compressor drive (1). After the turbine (3), the flow is directed to the power turbine (4), in which its final expansion takes place. The flow pressure practically decreases to atmospheric, and the temperature drops to $360 \div 500{ }^{\circ} \mathrm{C}$. The flow energy is converted into mechanical energy - the work of the blower drive (6). The combustion products enter the waste heat boiler (5), in which the fuel gas stream is heated, and then they are discharged into the atmosphere.

The process gas flow from the main pipeline enters the blower (6), in which the gas pressure rises to the set one. When the gas is compressed in the blower (6), its temperature rises by more than $40^{\circ} \mathrm{C}$. After the blower (6), the gas is cooled with air in the AC (7). In the existing scheme, gas is further directed to the main pipeline. 
In the proposed scheme, the gas is further cooled in an additional heat exchanger (10) with a cold flow of fuel gas, and then sent to the main gas pipeline.

Let's consider the results of an approximate calculation of the indicators of the utilization system for processing fuel gas. As an example of natural gas, let's took gas from the Dashavske field (Ukraine) with a methane content of $98.9 \%$. Taken as input:

- one GPU 16/56-1,44;

- process gas consumption - 29.9 million st. $\mathrm{m}^{3} /$ day fuel gas consumption - $4940 \mathrm{~nm}^{3} /$ hour;

- gas pressure at the inlet to the compressor station (CS) - 3.7 MPa;

- gas pressure at the compressor station outlet - 5.6 MPa;

- gas pressure at the outlet of the turboexpander $1.27 \mathrm{MPa}$;

- gas temperature at the inlet to the compressor station $-14{ }^{\circ} \mathrm{C}$;

- gas temperature at the outlet of the blower $(6)-49^{\circ} \mathrm{C}$, and after $\mathrm{AC}(7)-40{ }^{\circ} \mathrm{C}$;

- the efficiency of the turboexpander - $75 \%$;

- fuel gas temperature after the heat exchanger (10) -

$30{ }^{\circ} \mathrm{C}$, after the waste heat boiler $(5)-250{ }^{\circ} \mathrm{C}$;

- ignition temperature of the air-fuel mixture $-530{ }^{\circ} \mathrm{C}$.

The results of the positive effects from the utilization of excess energy.

The power of the expander-generator set with a decrease in fuel gas pressure $(N, \mathrm{~kW})$ is calculated by the formula:

$$
N=G \cdot H_{a d} \cdot \eta,
$$

where $G=1.066$ - fuel gas consumption through the expander, $\mathrm{kg} / \mathrm{s} ; \eta=0.75$ - efficiency takes into account energy losses in the turbo expander, gearbox and power generator.

The enthalpy drop during the adiabatic process of gas expansion in a turboexpander $H_{a d}, \mathrm{~kJ} / \mathrm{kg}$ :

$$
H_{a d}=\frac{k_{v}}{k_{v}-1} \cdot k \cdot R \cdot T_{1} \cdot\left[1-\left(\frac{P_{2}}{P_{1}}\right)^{\frac{k_{v}-1}{k_{v}}}\right]
$$

where $k_{v}=1.309$ - volumetric adiabatic exponent; $k=0.984-$ gas compressibility factor; $R=475 \mathrm{~J} /(\mathrm{kg} \cdot \mathrm{K})$ - individual gas constant; $T_{1}=287 \mathrm{~K}-$ expander inlet gas temperature; $P_{1}=3.7 \mathrm{MPa}-$ expander inlet gas pressure; $P_{2}=1.27 \mathrm{MPa}-$ expander outlet gas pressure.

The calculation results showed that with a decrease in the enthalpy of the fuel gas in the turboexpander by $127 \mathrm{~kJ} / \mathrm{kg}$, the electric power in the generator (9) is equal to $102 \mathrm{~kW}$.

The determination of the effect of subcooling of the process gas in a shell-and-tube heat exchanger (10) by a cold flow of fuel gas was carried out on the basis of the balance equation of heat transfer. Calculations have shown that the temperature of the process gas decreases by $0.3^{\circ} \mathrm{C}$. Fuel gas is heated from minus $40{ }^{\circ} \mathrm{C}$ to plus $30{ }^{\circ} \mathrm{C}$.

When the fuel gas passes through the heat exchanger in the waste heat boiler (5), its temperature rises from $30{ }^{\circ} \mathrm{C}$ to $250{ }^{\circ} \mathrm{C}$ due to heat exchange with hot combustion products. Accordingly, the energy consumption for the subsequent heating of the fuel gas to an ignition temperature of $530{ }^{\circ} \mathrm{C}$ is reduced. Taking into account the calorific value of fuel gas $34.9 \mathrm{MJ} / \mathrm{m}^{3}$, its savings due to heating to $250{ }^{\circ} \mathrm{C}$ will be $1.3 \%$ or $64 \mathrm{~nm}^{3} / \mathrm{h}$ of its consumption.
The question should be answered: «Why is the utilization of excess fuel gas energy not used?». The answer lies in the rationale. To utilize excess energy, equipment that is atypical for a compressor station should be used: a turbo expander and an electric generator. This equipment is not cheap and requires qualified service.

\section{SWOT analysis of research results}

Strengths. The strength of the investigated combined utilization system is its own consumption at the compressor station of the achieved positive effects. The permissible heating of fuel gas up to $300{ }^{\circ} \mathrm{C}$ due to secondary heat resources allows to reduce its consumption by $1.5 \%$. In monetary terms, as applied to the J-59 engine, the daily savings will amount to 400-500 USD at a gas cost of 200-250 USD per $1000 \mathrm{~m}^{3}$.

Energy recovery from fuel gas overpressure for the production of electrical energy leads to a reduction in electricity consumption at the station from external sources. The process gas air cooler for GPU 16/56-1.44 has an installed power of electric motors of $74 \mathrm{~kW}$. The received electricity of $102 \mathrm{~kW}$ will ensure the operation of the air cooler in full. At a cost of electricity of 10 cents per $1 \mathrm{kWh}$, the monetary savings from the operation of the AC will amount to 7.4 USD per hour.

In the analogs of the combined utilization system considered above, the noted positive effects are not achieved.

Weaknesses. New equipment for utilizing excess energy at a compressor station requires a significant investment. The estimated cost of the two regenerative heat exchangers is 10000 USD. The estimated cost of the expandergenerator set is 70 thousand dollars in relation to the GPU 16/56-1.44.

Opportunities. Prospects for further research are presented in the study of possible solutions to the problem in relation to a specific compressor station. It is known [3] that several (on average five) gas pumping units operate in parallel for one main gas pipeline. How will the combined disposal systems be operated in this case?

Threats. Turbo expanders and power generators are atypical equipment for compressor stations. Their operation requires additional skilled labor resources.

\section{Conclusions}

1. A solution is proposed for utilizing the excess pressure of the fuel gas of a gas turbine engine. The solution to the problem is considered on the basis of a new combined utilization system. The system includes an expander-generator set, a heat exchanger for cooling the high-pressure process gas and a heat exchanger for heating the fuel gas in the waste heat boiler before it is burned in the combustion chamber. The structure of the combined system allows to obtain a number of positive effects. On the example of the gas-pumping unit GPU 16/56-1.44 the modeling of the characteristics of the new combined utilization system was carried out.

2. It is shown that additional electrical power of $102 \mathrm{~kW}$ is essential for the operation of electrical equipment at a compressor station. Subcooling of the process gas in heat exchanger 10 (Fig. 3) is 10-30 times less than the Joule-Thomson effect and heat exchange of gas with soil in the linear part of the gas pipeline. It does not play 
a significant role. Regenerative heating of fuel gas in waste heat boiler 5 (Fig. 3), essential for saving fuel gas.

\section{References}

1. Garris, N. A. (2009). Resursosberegaiuschie tekhnologii pri magistralnom transporte gaza. Saint Petersburg: OOO «Nedra», 368

2. Kologrivov, M. M., Sagala, T. A., Buzovskii, V. P. (2015). Kotliutilizatori. Odessa: FOP Bondarenko M. O., 84.

3. Kozachenko, A. N., Nikishin, V. I., Porshakov, B. P. (2001). Energetika truboprovodnogo transporta gazov. Moscow: GUP Izdatelstvo «Neft i gaz» RGU nefti i gaza im. I. M. Gubkina, 400.

4. Shelkovskii, B. I., Pashotchenko, A. S., Zakharov, V. P. (1991) Utilizatsiia $i$ ispolzovanie vtorichnykh energoresursov kompressornykh stantsii. Moscow: Nedra, 180.

5. Shubenko, O. L., Sarapin, V. P., Sarapina, M. V., Kulish, V. M. (2018). Energy saving at gas compressor station by efficient use of fuel gas overpressure energy. Bulletin of the National Technical University «KhPI». Series: Hydraulic machines and hydraulic units, 46 (1322), 10-16. Available at: http://repositsc.nuczu. edu.ua/handle/123456789/8809

6. Stepanets, A. A.; Trukhnii, A. D. (Ed.) (1999). Energosberegaiuschie turbodetandernye ustanozki. Moscow: Nedra-Biznestsentr, 258.

7. Javadi, S. M., Moghiman, M. (2012). Experimental study of natural gas temperature effects on the flame luminosity and NO emission. International Journal of Spray and Combus tion Dynamics, 4 (2), 175-184. doi: http://doi.org/10.1260/ 1756-8277.4.2.175

8. Basha, M., Shaahid, S. M., Al-Hadhrami, L. (2012). Impact of Fuels on Performance and Efficiency of Gas Turbine Power Plants. Energy Procedia, 14, 558-565. doi: http://doi.org/10.1016/ j.egypro.2011.12.975
9. Marin, G., Mendeleev, D., Osipov, B., Akhmetshin, A. (2020) Study of the effect of fuel temperature on gas turbine performance. E3S Web of Conferences, 178, 01033. doi: http:// doi.org/10.1051/e3sconf/202017801033

10. Marin, G. E., Mendeleev, D. I., Osipov, B. M. (2021). A study on the operation of a gas turbine unit using hydrogen as fuel. Journal of Physics: Conference Series, 1891 (1), 012055. doi: http://doi.org/10.1088/1742-6596/1891/1/012055

11. Khalatov, A. A., Dolinskii, A. A., Kostenko, D. A., Parafeinik, V. P (2010). Sostoianie i problemy razvitiia mekhanicheskogo privoda dlia GTS Ukrainy. Promyshlennaia teplotekhnika, 32 (1), 44-53. Available at: http://dspace.nbuv.gov.ua/bitstream/ handle/123456789/60483/07-Khalatov.pdf?sequence $=1$

12. Kompressornoe oborudovanie $i$ gazoperekachivaiuschie agregaty (2019). Sumy: PAO «Sumskoe NPO», 151. Available at: http:// snpo.ua/wp-content/uploads/2017/06/sumy_npo_compressor equipment and GPU_ru.pdf

13. Tekhnicheskie kharakteristiki gazoturbinnykh agregatov i ustanovok «Zoria - Mashproekt». Available at: https://manbw.ru/analitycs/ tehnicheskie-harakteristiki-gazoturbinnyh_zorya-mashproekt.html

Mykhail Kologrivov, PhD, Associate Professor, Department of Oil and Gas Technologies, Engineering and Heat Power Engineering, Odessa National Academy of Food Technologies, Odessa, Ukraine, ORCID: https://orcid.org/0000-0003-1959-8615

$\triangle$ Vitalii Buzovskyi, PhD, Assistant, Department of Oil and Gas Technologies, Engineering and Heat Power Engineering, Odessa National Academy of Food Technologies, Odessa, Ukraine, ORCID: https:// orcid.org/0000-0001-6718-5001, e-mail: buzovskiy.v@gmail.com

$\triangle$ Corresponding author 